ADDIN, Vol. 10, No. 1, Februari 2016

\title{
MANAJEMEN KURIKULUM DALAM PERSPEKTIF ANTI-RADIKALISME
}

\author{
Kisbiyanto \\ STAIN Kudus, Jawa Tengah, Indonesia \\ kisbiyanto@gmail.com
}

\section{Abstrak}

Manajemen kurikulum di perguruan tinggi keagamaan Islam negeri (PTKIN) mempunyai peran strategis dalam mencapai visi penyelenggaraan pendidikan tinggi, apalagi di Indonesia yang mayoritas berpenduduk muslim. PTKIN mempunyai tanggungjawab dalam pengembangan kerukunan umat beragama dan mentransformasikan nilai-nilai Islam yang damai dan anti-radikalisme. Tujuan penelitian ini (1) perencanaan kebijakan kurikulum bagi pendidikan agama Islam berperspektif anti-radikalisme di STAIN Kudus, dan (2) isi kurikulum bagipendidikan agama Islam berperspektif anti-radikalisme di STAIN Kudus. Metode penelitian dengan pendekatan kualitatif. Data dikumpulkan dengan teknik dokumentasi, dan keabsahan triangulasi. Analisis data secara interakstif. Hasil penelitian ini bahwa (1)kebijakan perencanaan kurikulum pada Program Studi Pendidikan Agama Islam Sekolah Tinggi Agama Islam Negeri Kudus dilakukan dengan penyusunan secara periodik mulai kurikulum 1997, kurikulum 2003, dan kurikulum 2008. Kurikulum dari tigaperiode itu dilakukan evaluasi dan penyusunan kembali bingga melibatkan para dosen dan abli, baik dari dalam lembaga maupun abli dari luar. Kurikulum itu disebut kurikulum dengan pendekatan pola corelated curriculum, yaitu pendekatan dengan pola pengelompokan beberapa mata kuliah yang serumpun. Artinya, kurikulum 2008 ini tidak kurikulum yang berpendekatan dengan polasubject matter curriculum, atau pendekatan yang menekankan pada mata kuliah secara terpisah-pisah. Mata kuliah 
Kisbiyanto

klasifikasikan menjadi 5 kelompok, yaitu mata kuliah pengembangan kepribadian (MPK), mata kuliah keilmuan dan keterampilan (MKK), mata kuliah keahlian berkarya (MKB), mata kuliah perilaku berkarya (MPB), mata kuliah berkehidupan bermasyarakat (MBB). (2)Isi kurikulum Pendidikan Agama Islam secara substansi tersebar di hampir semua mata kuliah dengan konten pada kecenderungan kurikulum dan pembelajaran yang anti-radikalisme, yaitu suatu wacana dan gerakan keislaman yang mengutamakan pendidikan dan dakwah secara damai, toleransi, mengutamakan kemanusiaan, dan menghormati perbedaan sebagai rahmat bagi semesta alam.

Kata Kunci: Manajemen Kurikulum, Anti-Radikalisme.

\section{Abstract}

THE CURRICULUM MANAGEMENT FROM THE ANTI-RADICALISM PERSPECTIVE: The curriculum management in the college of Islamic religious affairs (PTKIN) has a strategic role in achieving the vision of the implementation of the higher education especially in Indonesia that has the majority muslim population. PTKIN is responsible in the development of religious harmony and transform the Islamic values that peace and anti-radicalism. The purpose of this research is: (1) designing the Islamic education policy in anti-radicalism perspective at STAIN Kudus; (2) the contents of the curriculum for Islamic education anti-radicalism perspective in STAIN Kudus. This research is used qualitative approach. The data collected by the documentation technique and the triangulation validity. Data analysis by interactive. The results of this research is: (1) Curriculum planning policy Islamic Education department STAIN Kudus is arrangement periodically start from the curriculum 1997, 2003, and 2008. The three periods of curriculum is re-arrange and evaluated by involve the lecturers and experts. This curriculum pattern is called curriculum corelated approach; it is classified from one family courses. This means that the curriculum 2008 is not the curriculum with subject pattern matte curriculum aproach, it emphasizes on courses in a separate settlements. The elective courses is clasified into five groups, namely personality development courses (MPK), scholarly and skills (MKK), courses work (MKB), behavior courses work (MPB), social life courses (MBB). (2) The Islamic education curriculum substance is spread in 
almost all courses and content on the tendency of the anti-radicalism curriculum and learning, it is a Islamic movements and discourse that give education and peacefull dakwah as a prior, tolerance, humanity, and respect differences as a mercy for the universe.

Keywords: Curriculum Management, Anti-Radicalism.

\section{A. Pendahuluan}

Perguruan tinggi keagamaan Islam negeri (PTKIN) di Indonesia, jumlahnya tidak terlalu banyak jika dilihat dari wilayah, jumlah provinsi, dan pemerataannya. PTKIN merupakan pusat pendidikan dan dakwah Islam yang difasilitasi oleh pemerintah dan negara. Sebagai pusat pendidikan dan dakwah, PTKIN harus menjaga marwahnya, yaitu penebar Islam yang damai. Bentuk perguruan tinggi keagamaan Islam negeri, berupa Sekolah Tinggi Agama Islam Negeri (STAIN), Institut Agama Islam Negeri (IAIN), dan Universitas Islam Negeri (UIN). Jumlahnya ada 55 perguruan tinggi yang tersebar dari Aceh hingga Papua. Dalam perkembangannya, PTKIN mengalami berbagai perubahan, terutama status kelembagaan dari perguruan tinggi swasta menjadi IAIN, kemudian IAIN fakultas cabang menjadi STAIN, dan IAIN menjadi UIN, serta STAIN menjadi IAIN dan/atau menjadi UIN. Perubahan-perubahan tersebut juga berdampak pada penyiapan infrastruktur kelembagaan, termasuk visi yang merupakan cermin keadaan internal dan kehandalan inti seluruh kelembagaan pendidikan ${ }^{1}$, misi, dan termasuk kurikulum. Apalagi trend PTKIN sekarang ini menjadi world class university merupakan sebuah instrumen untuk menjadikan visi Islam yang mendunia sebagai proyek peradaban yang terus menerus berkelanjutan ${ }^{2}$, dan bukan sebaliknya yang menjadi mundur dan kerdil seperti beberapa kasus tentang radikalisme agama.

${ }^{1}$ Chusnul Chotimah dan Muhammad Fathurrohman, Komplemen Manajemen Pendidikan Islam - Konsep Integratif Pelengkap Manajemen Pendidikan Islam, ( Yogyakarta: Teras, 2014), hlm. 7.

${ }^{2}$ Baharuddin, Prospektus Menuju World Class University dalam Reorientasi Tradisi Perguruan Tinggi Islam Menuju World Class University, (Malang: UIN Maliki Press, 2014), hlm. 1. 
UIN, IAIN, danSTAIN sebagai perguruan tinggi keagamaan Islam negeri di bawah naungan Kementerian Agama Republik Indonesia, mempunyai dua mandat utama, yaitu penyelenggaraan pendidikan tinggi, serta dakwah dan kerukunan umat beragama di Indonesia. Artinya, keberadaan PTKIN merupakan bagian dari sistem berbangsa dan bernegara yang sudah dilandaskan secara filosofi kebangsaannya berdasarkan Pancasila dan Undang-Undang Dasar 1945. Kehidupan beragama di Indonesia bersandar pada kerukunan umat beragama, oleh karena itu perguruan tinggi keagamaan Islam mempunyai tanggung jawab besar untuk menjaga, melestarikan, dan mengembangkannya. Kerukunan umat beragama di Indenesia sudah menjadi budaya nasional yang penuh kedamaian dan nasionalisme kebangsaan. Berbeda-beda agama, tetapi tetap satu dalam Negara Kesatuan Republik Indonesia.

Indonesia sebagai negara beragama, menempati urutan tertinggi sebagai negara berpenduduk muslim terbesar di dunia. Indonesia secara politik maupun hukum meneguhkan keberpihakannya atas kedaulatan negara di dunia ini, dan selalu ikut aktif dalam upaya penciptaan perdamaian dunia. Berkaitan dengan perdamaian dunia, perhatian dunia sekarang ini tertuju pada isu internasional yang terkait dengan agama dan terorisme. Meskipun terorisme bukan fenomena baru, yang berarti sudah terjadi aksi-aksi serupa pada zaman-zaman dahulu, tetapi tertorisme menjadi isu hangat dan menyita perhatian karena ada konteks radikalisasi agama yang melatarbelakangi aksi-aksi terorisme itu. Radikalisasi agama yang menyeruak hampir di seluruh dunia sekarang ini, ternyata radikalisasi paham keagamaan Islam oleh sebagaian orang yang memahami dan menafsirkan tekstualitas agama secara radikal. Islam menjadi tertuduh yang menanggung dosa sosial terberat dalam sejarah sekarang ini. Karena itu Indonesia sebagai negara dengan jumlah muslim terbesar mempunyai tanggung jawab besar untuk mengantisipasi dan mengatasinya dengan upaya deradikalisasi paham keagamaan. Perdebatan panjang tentang relasi negara dan agama telah membentuk konsensus nasional dalam bentuk principal ideology Pancasila yang menjawab masalah ketegangan hubungan agama 
dan negara ${ }^{3}$. Indonesia bukan negara agama, tetapi menjamin kebebasan warganya untuk beragama dan melaksanakannya dengan sebaik-baiknya. Karena itu, aksi radikal dan terorisme atas nama agama sungguh tidak bisa dibenarkan dalam konteks kehidupan keberagamaan di Indonesia.

Deradikalisasi paham keagamaan Islam, jelas akan menjadi tugas dan konsentrasi para ilmuwan, ahli, dan praktisi di perguruan tinggi keagamaan Islam. Isu terorisme yang bersumber pada radikalisasi paham keagamaan merupakan produk dakwah dan pendidikan yang keliru. Karena itu pendidik mempunyai peran penting dalam perencanaan, proses pembelajaran, dan penilaian pendidikan, termasuk dalam menyusun kurikulum yang tidak radikal, tetapi yang moderat. Karena itu, PTKIN sebagai pusat pendidikan dan dakwah keislaman, memerlukan para profesional berkompetensi, termasuk juga kompetensi dosen dalam mengembangkan visi, kurikulum, dan pembelajaran yang menunjukkan Islam moderat. Perkembangan pendidikan dewasa ini adalah orientasi pendidikan yang ditujukan pada kompetensi di berbagai bidang untuk menghadapi dunia global. Kompetensi itu menunjuk pada penyiapkan sumber daya manusiayang berkualitas dan siap berperan pada tingkat nasional maupun internasional melalui pendidikan dan dakwah keislaman. Kompetensi sarjana dan lulusan dalam kajian keislaman Indonesia dibangun bersumber pada al-Qur'an dan Sunnah Rasul, dan khazanah budaya muslim di nusantara. Indonesia bisa menjadi rujukan dalam hal Islam damai itu, yang merupakan hasil panjang dari terbangunnya jejaring ulama-santri (kaum agama) dalam melakukan perlawanan kepada kolonialisme ${ }^{4}$, hampir sama dengan situasi sekarang di mana kaum intelektual muslim harus melakukan perlawanan kepada radikalisme maupun terorisme.

Visi merupakan faktor terpenting dan pertama dalam penyelenggaraan pendidikan. Visi terkait erat dengan manajemen

${ }^{3}$ Ali Masykur Musa, Nasionalisme di Persimpangan - Pergumulan NU dan Paham Kebangsaan Indonesia, (Jakarta: Penerbit Erlangga, 2011), hlm. 147.

${ }^{4}$ Zainul Milal Bizawie, Laskar Ulama-Santri \& Resolusi Jihad - Garda Depan Menegakkan Indonesia 1945-1949, (Tangerang: Pustaka Compass, 2014), hlm. 59. 
strategik yang melibatkan suatu proses kontinu dan interaktif dalam mencapai tujuan pendidikan sesuai dengan kondisi lingkungan yang dihadapinya, termasuk untuk pengembangan sumber daya manusia, alam, dan buatan lainnya ${ }^{5}$, misalnya kurikulum. Namun demikian, masalah-masalah terkait dengan pendidikan, terutama di perguruan tinggi pada umumnya terfokus pada isu-isu pendidikan yaitu masalah pemerataan pendidikan, masalah kualitas atau mutu pendidikan, masalah efisiensi dan efektifitas pendidikan dan masalah relevansi pendidikan ${ }^{6}$, yang berarti sebagai masalah manajemen kependidikan. Pemerataan dan mutu pendidikan bahkan masih menjadi beban bagi tenaga pendidik, karena dosen di PTKIN minimal seorang magister, dan sebaiknya seorang doktor. Dosen sebagaimana diamanatkan oleh Undang-Undang Republik Indonsia Nomor 14 tahun 2005 tentang Guru dan Dosen, harus mempunyai empat kompetensi utama, yaitu pedagogik, kepribadian, profesional dan sosial. Keempat kompetensi itu juga menjadi entry point bagi pelaksaan tugasnya, yaitu mendidik dan mengajar, meneliti, dan mengabdi pada masyarakat.

Kendala umum dalam pengajaran di perguruan tinggi adalah masalah kurikulum. Kurikulum yang memuat penjelasanpenjelasan yang radikal akan menjadi pemicu paham-paham kekerasan atas nama agama. Karena itu kurikulum tidak boleh statis karena akan menjadi materi perkuliahan yang tertinggal dengan perkembangan dan kemajuan. Kurikulum harus dinamis, sesuai dengan perkembangan sosial budaya, bahkan perkembangan dunia, dan lebih khusus lagi sesuai dengan perkembangan kajian keislaman yang kontemporer dan bersifat kontekstual. Kurikulum yang baik adalah yang selalu dipelajari kembali sehingga sesuai dengan visi pendidikan dalam pembentukan kepribadian dan keahlian manusia ${ }^{7}$. PTKIN sebagai perguruan tinggi setiap

${ }^{5}$ Musa Hubeis dan Mukhamad Najib, Manajemen Strategik dalam Pengembangan Daya Saing Organisasi, (Jakarta: Kompas Gramedia, t.t), hlm. 6.

${ }^{6}$ Retno Sriningsih Satmoko. 1999. Landasan Kependidikan: Pengantar ke Arah Ilmu Pendidikan Pancasila, (Semarang: IKIP Semarang Press, 1999), hlm. 207.

${ }^{7}$ HAR Tilaar, Pendidikan, Kebudayaan dan Masyarakat Madani Indonesia. (Bandung: Remaja Rosda Karya, 1999), hlm. 17. 
tahun dan selambatnya setiap lima tahun sekali harus melakukan pengembangan kurikulum dalam bentuk peninjauan kurikulum. Namun, peninjauan itu bukan hanya berdampak administratifformalistik, tetapi harus menjadi elan vital pengembangan kurikulum yang merespon perkembangan ilmu, pengetahuan, teknologi, dan kebutuhan masyarakat dunia saat ini, yaitu Islam yang damai untuk semua.

Kendala lain dalam kurikulum adalah tentang isi kurikulum yang tidak sesuai dengan tujuan yang diharapkan. Isi kurikulum seharusnya merujuk pada rumusan tujuan atau sesuai dengan visi dan misi pendidikan, baik kebangsaan maupun kelembagaan. Kesenjangan ini harus diatasi dengan upaya penyesuaian terhadap tujuan. Komponen kurikulum ${ }^{8}$ yang terdiri dari tujuan, bahan pelajaran, proses belajar mengajar dan penilaian harus dirumuskan secara serasi, selaras dan seimbang, baik untuk kurikulum nasional maupun kurikulum muatan lokal. Kurikulum pendidikan keagamaan di Indonesia adalah berwawasan Pancasila dan mengutamakan nasionalisme kebangsaan yang cinta damai dan berkeadilan sosial. Kurikulum yang berwawasan paham radikalis keagamaan, tidak semestinya diperbolehkan untuk diajarkan kepada mahasiswa.

Kendala lebih khusus dalam pemberlakuan kurikulum adalah yang terkait dengan evaluasi, yang menjadi ukuran keberhasilan suatu tindak pendidikan. Evaluasi terkadang kurang terukur sehingga evaluasi dilakukan tanpa standarisasi sesuai kurikulum yang ideal. Evaluasi sebagai komponen penting kurikulum juga sering tidak dirumuskan secara jelas, meskipun tidak semua aspek penilaian itu diukur dengan angka. Kejelasan standarisasi evaluasi pada rumusan kurikulum akan membantu upaya pencapaian tujuan melalui proses evaluasi yang valid dan reliabel. Meskipun terkesan formal, standarisasi evaluasi pendidikan di PTKIN akan berdampak pada suatu titik yang divisikan, yaitu menguasai dan mengamalkan ajaran Islam yang moderat, tidak radikal.

Sisi lain yang melatarbelakangi kajian ini adalah tentang kompetensi dalam pendidikan keagamaan Islam yang tertampung

${ }^{8}$ S. Nasution, Pengembangan dan Inovasi Kurikulum, Jakarta: Citra Aditya Bakti, 1993), hlm. 3-4.

ADDIN, Vol. 10, No. 1, Februari 2016 
pada PTKIN. Struktur dan karakteristik ilmu-ilmu yang dipelajari dan dikembangkan di perguruan tinggi pada umumnya bersifat terbuka, general dan belum membumi sehingga membutuhkan pengembangan dan pemberdayaan lebih lanjut. Upaya ini dalam satu sisi merupakan bagian dari sistem perencanaan institusional yang sudah dirumuskan sebelumnya, dan dalam sisi yang lain merupakan respon terhadap kebijakan baru kurikulum pendidikan di Indonesia yang berciri kurikulum berbasis kompetensi dan atau keterampilan. Upaya-upaya pengembangan kurikulum di perguruan tinggi tersebut sangat menarik karena merupakan bidang penting dalam perkembangan pendidikan dewasa ini. Dengan berbagai alasan dan latar belakang di atas, kajian ini dilakukan dengan judul

\section{B. Pembahasan}

\section{Manajemen Kurikulum Berperspektif Anti-Radikalisme di Perguruan Tinggi}

Menurut Subandijah' yang dimaksud kurikulum adalah "aktifitas dan kegiatan belajar yang direncanakan, diprogramkan bagi peserta didik di bawah bimbingan sekolah, baik di dalam maupun di luar sekolah". Isi definisi tersebut dapat diklasifikasi menjadi dua substansi, yaitu (a) kurikulum sebagai program yang direncanakan dan dilaksanakan di sekolah dan (b) kurikulum sebagai program yang direncanakan dan dilaksanakan secara nyata di kelas. Perencanaan program dan pelaksanaannya tersebut dimaksudkan untuk mencapai tujuan pendidikan yang telah ditetapkan. Dengan demikian, kurikulum berkedudukan sebagai alat untuk mencapai tujuan pendidikan.

Pendidikan tinggi di Indonesia melaksanakan proses pembelajaran dengan mengacu pada kurikulum nasional. Di samping itu, lembaga pendidikan juga menerapkan kurikulum muatan lokal yang ditentukan oleh masing-masing satuan lembaga pendidikan. Kedua macam kurikulum itu merupakan keharusan bagi setiap lembaga pendidikan untuk menerapkannya. Menurut

'Subandijah, Pengembangan dan Inovasi Kurikulum, Jakarta: Raja Grafindo Persada, 1996), hlm. 2-3. 
UU RI No. 20 Tahun 2003, kurikulum pendidikan wajib memuat pendidikan agama, pendidikan kewarganegaraan, bahasa, dan ilmu-ilmu dasar dan ilmu-ilmu terapan yang mendukung tujuan pendidikan masing-masing fakultas, jurusan, dan program studi.

Aksi pelaksanaan kurikulum sering kali dilengkapi dengan lembar kerja atau lembar tugas yang harus dikerjakan oleh mahasiswa. Namun, pertanyaan yang diajukan dalam lembar kerja atau lembar tugas itu serign berupa pertanyaan yang kurang memicu mahasiswa beroikir tingkat tinggi, semisal menganalasis, mengevaluasi, atau mengkreasi. ${ }^{10}$ Jadi disamping materi yang telah ditentukan secara nasional, sebuah lembaga pendidikan harus menentukan dan mengajarkan kurikulum muatan lokal yang didesain, diajarkan dan diujikan di lembaga pendidikan tersebut.

\section{Pengembangan Kurikulum}

Pengembangan kurikulum adalah "kegiatan menghasilkan kurikulum baru melalui langkah-langkah penyusunan, pelaksanaan dan penyempurnaan kurikulum atas dasar hasil penilaian yang dilakukan selama kegiatan pengembangan tersebut" ${ }^{11}$. Sedang pengembangan kurikulum menurut Centre for Educational Research and Innovation (CERI) dalam rumusan Soetopo didefinisikan sebagai berikut: curriculum development is the proces of analizing and refining goals, aims and objectives, together with the translation of these into the content of course by formal or informal methods ${ }^{12}$. Kegiatan pengembangan kurikulum meliputi penyusunan kurikulum, pelaksanaannya di dalam proses belajar mengajar dan penyempurnaan terhadap komponen-komponen tertentu atas dasar hasil penilaian.

Pengembangan kurikulum didasarkan atas asas-asas tertentu ${ }^{13}$, yaitu: (a) asas filosofis yang pada hakekatnya menentukan tujuan umum pendidikan, (b) asas sosiologis yang memberikan dasar untuk menentukan apa yang akan dipelajari

${ }^{10}$ Abdul Majid, Strategi Pembelajaran, (Bandung: Remaja Rosdakarya, 2013), hlm. 327.

${ }^{11}$ Henyat Soetopo dan Wasty Soemanto, Pembinaan dan Pengembangan Kurikulum, (Jakarta: Bima Aksara, 1986), hlm. 41.

${ }^{12}$ Ibid., hlm. 45.

${ }^{13}$ S. Nasution, Pengembangan dan Inovasi Kurikulum, hlm. 1-2. 
sesuai dengan kebutuhan masyarakat, budaya dan perkembangan ilmu pengetahuan dan teknologi, (c) asas organisatoris yang memberikan dasar-dasar dalam bentuk bagaimana bahan pelajaran disusun dan bagaimana luas dan urutannya, dan (d) asas psikologis yang memberikan prinsip-prinsip tentang perkembangan manusia dalam berbagai aspek serta cara belajar agar bahan yang disediakan dapat dicerna dan dikuasai peserta didik sesuai dengan taraf perkembangannya.

Landasan pengembagan kurikulum dapat menjadi titik tolak sekaligus menjadi titik sampai ${ }^{14}$. Titik tolak berarti pengembangan kurikulum dapat didorong oleh pembaharuan tertentu seperti penemuan teori belajar yang baru dan perubahan tuntutan masyarakat terhadap fungsi lembaga pendidikan. Titik sampai berarti kurikulum harus dikembangkan sedemikian rupa sehingga dapat merealisasikan perkembangan tertentu, seperti dampak kemajuan ilmu pengetahuan dan teknologi, tuntutan-tuntutan sejarah masa lalu, perbedaan latar belakang peserta didik, nilai-nilai filsafat suatu masyarakat dan tuntutan-tuntutan kultur tertentu.

Perencanaan ${ }^{15}$ adalah penggunaan analisis yang bersifat rasional dan sistematis terhadap proses pengembangan pendidikan yang bertujuan untuk menjadikan pendidikan lebih efektif dan efisien dalam menanggapi kebutuhan dan tujuan peserta didik dan masyarakat. Ada empat persoalan penting yang dibahas dalam perencanaan, yaitu (a) tujuan apa yang dicapai dengan perencanaan itu, (b) status sistem pendidikan yang ada dan bagaimana keadaannya sekarang, (c) kemungkinan-kemungkinan pilihan apa yang ditempuh untuk mencapai tujuan, dan (d) strategi yang terbaik untuk mencapai tujuan.

Jadi perencanaan dalam pendidikan adalah sebagai fungsi manajemen pendidikan. Fungsi perencanaan tersebut adalah untuk menentukan keadaan yang sebaik-baiknya dari hubunganhubungan sumber daya internal dan eksternal dalam suatu sistem

\footnotetext{
${ }^{14}$ Henyat Soetopo dan Wasty Soemanto, Pembinaan dan Pengembangan Kurikulum, hlm. 46.

${ }^{15}$ St. Vembriarto, Pengantar Perencanaan Pendidikan, (Jakarta: Grasindo, 1993), hlm. 28.
} 
pendidikan dengan keadaaan yang dinamis serta cara yang efisien dan efektif untuk mencapai tujuan yang diinginkan.

Salah satu sumber daya yang harus direncanakan adalah "materi pendidikan" atau kurikulum. Sumber daya "kurikulum" ini membutuhkan perencanaan yang tepat dan strategis. Hasil perencanaan kurikulum yang baik menentukan keberhasilan dalam pencapaian tujuan pendidikan. Dalam konteks perkembangan, kurikulum harus selalu dikembangkan. Fungsi perencanaan kurikulum dan pengembangnnya itu dimaksudkan untuk pengelolaan pendidikan agar tidak mengalami ketertinggalan.

Ada tiga faktor umum yang mendorong pengembangan kurikulum $^{16}$, yaitu (a) perubahan yang diinginkan masyarakat sehingga mereka merencanakan adanya perubahan yang cukup penting di dalam kurikulum dan sistem pendidikan, (b) perkembangan ilmu pengetahuan dan teknologi yang pesat, dan (c) pertambahan pesat penduduk dunia.Proses pengembangan kurikulum dijalankan karena (a) hasil penelitian dan pengembangan, (b) interaksi sosial, dan (c) metode pemecahan masalah ${ }^{17}$.

\section{Prinsip-prinsip Pengembangan Kurikulum}

Prinsip-prinsip dasar pengembangan kurikulum meliputi ${ }^{18}$ : (a) prinsip relevansi, yang meliputi relevansi dengan lingkungan, perkembangan masa dan tuntutan dunia kerja, (b) prinsip efektifitas yang meliputi efektifitas mengajar pendidik dan efektifitas belajar peserta didik, (c) prinsip efisiensi dalam penggunaan sumber daya pendidikan.

Prinsip-prinsip pengembangan kurikulum ${ }^{19}$ adalah: (a) prinsip relevansi, (b) prinsip efektifitas dan efisiensi, (c) prinsip kesinambungan, (d) prinsip fleksibilitas, (e) prinsip berorientasi pada tujuan, (f) prinsip pendidikan seumur hidup, dan (g) prinsip kesesuaian dengan model pengembangan kurikulum. Pendekatan

\footnotetext{
${ }^{16}$ Henyat Soetopo dan Wasty Soemanto, Pembinaan dan Pengembangan Kurikulum, hlm. 40-41.

${ }^{17}$ S. Nasution, Pengembangan dan Inovasi Kurikulum, hlm. 159.

${ }^{18}$ Henyat Soetopo dan Wasty Soemanto, Pembinaan dan Pengembangan Kurikulum, hlm. 48.

${ }^{19}$ Subandijah, Pengembangan dan Inovasi Kurikulum, hlm. 48.
} 
dalam pengembangan kurikulum diorientasikan pada (a) tujuan pendidikan dan (b) bahan pelajaran. Subandijah ${ }^{20}$ mengemukakan tiga pendekatan dengan pola organisasi bahan sebagai berikut: (a) pendekatan dengan pola subject matter curriculum, yaitu pendekatan yang menekankan pada mata pelajaran/mata kuliah secara terpisah-pisah, (b) pendekatan dengan pola corelated curriculum, yaitu pendekatan dengan pola pengelompokan beberapa mata kuliah yang seiring (serumpun), dan (c) pendekatan dengan pola integrated curriculum, yaitu pendekatan dengan penyatuan keseluruhan mata kuliah sebagai bahan ajar yang sistematik- integralistik.

Langkah-langkah utama dalam perencanaan kurikulum --misalnya dengan model Tyler meliputi ${ }^{21}$ (a) menentukan tujuan pendidikan, (b) menentukan proses belajar mengajar, (c) menentukan organisasi kurikulum, dan (d) menentukan cara penilaian hasil belajar. Adapun tahap-tahap dalam pengembangan kurikulum menurut Subandijah ${ }^{22}$ adalah: (a) pengembangan kurikulum pada tingkat lembaga, (b) pengembangan kurikulum pada tingkat/setiap bidang studi, dan (c) pengembangan pengajaran di kelas.

Tahap-tahap pengembangan kurikulum di perguruan tinggi dijalani secara terstruktur, sepanjang masa dari tahun ke tahun selama satu periode pemberlakuan kurikulum berkisar antara 4 hingga 5 tahun. Menurut Keputusan Menteri Pendidikan Nasional Nomo 232/U/2000, kurikulum pada perguruan tinggi untuk program sarjana (S1) berkisar antara 144 s/d 160 sks, sedangkan untuk program magister (S2) berkisar 36 s/d 50 sks, dan untuk program doktor (S3) berkisar $40 \mathrm{~s} / \mathrm{d} 52 \mathrm{sks}$.

\section{Pendidikan Islam}

Pendidikan mempunyai nilai dari aspek pengertiannya, yaitu at-tarbiyah, at-ta'lim, dan at-ta'dib. Para pakar pendidikan Islam memberikan menjelasan yang beraragam namun mempunyai titik temu bahwa pendidikan Islam pada hakekatnya mempunyai banyak makna.Pertama, pendidikan Islam dalam disebut al-

\footnotetext{
${ }^{20}$ Ibid., hlm. 55.

${ }^{21}$ S. Nasution, Pengembangan dan Inovasi Kurikulum, hlm. 140.

${ }^{22}$ Subandijah, Pengembangan dan Inovasi Kurikulum, hlm. 215.
} 
tarbiyah yang berasal dari kata rabb ${ }^{23}$. Walaupun kata ini memiliki banyak arti, akan tetapi pengertian dasarnya menunjukkan makna tumbuh, berkembang, memelihara, merawat, mengatur, dan menjaga kelestarian atau eksistensinya. Dalam penjelasan lain, kata al-tarbiyah berasal dari tiga kata, yaitu: Pertama, rabba-yarbu yang berarti bertambah, tumbuh, dan berkembang Q.S. ar-Rum [30]: 39. Kedua, rabiya-yarba berarti menjadi besar. Ketiga, rabbayarubbu berarti memperbaiki, menguasai urusan, menuntun, dan memelihara. Kata rabb sebagaimana yang terdapat dalam QS. Q.S. al-Fatihah [1]: 2(alhamdu li Allahi rabb al-'áamin) mempunyai kandungan makna yang berkonotasi dengan istilah al-Tarbiyah. Sebab kata rabb (Tuhan) dan murabbi (pendidik) berasal dari akar kata yang sama. Berdasarkan hal ini, maka Allah adalah Pendidik Yang Maha Agung bagi seluruh alam semesta.

Pendidikan dalam bahasa Arab ${ }^{24}$ biasa disebut dengan istilah tarbiyah yang berasal dari kata kerja rabba, sedang pengajaran dalam bahasa Arab disebut dengan ta'lim yang berasal dari kata kerja 'allama. Pendidikan Islam sama dengan Tarbiyah Islamiyah. Kata rabba beserta cabangnya banyak dijumpai dalam Al-Qur'an, misalnya dalam QS. Al-Isra' [17]:24 dan QS. Asy-Syu'ara' [26]:18, sedang kata 'allama antara lain terdapat dalam QS. al-Baqarah [2]:31 dan QS. an-Naml [27]:16. Tarbiyah sering juga disebut ta'dib seperti sabda Nabi Saw: addabani rabbi fa absana ta'dibi (Tuhanku telah mendidikku, maka aku menyempurnakan pendidikannya).

Pendidikan yang dalam bahasa Arab disebut tarbiyah itu merupakan derivasi dari kata rabb seperti dinyatakan dalam QS. al-Fatihah [1]:2, Allah sebagai Tuhan semesta alam (rabb al'alamin), yaitu Tuhan yang mengatur dan mendidik seluruh alam. Allah memberikan informasi tentang arti penting perencanaan, penertiban, dan peningkatan kualitas alam. Manusia diharapkan selalu memuji kepada Tuhan yang mendidik alam semesta karenanya manusia juga harus terdidik agar memiliki kemampuan

${ }^{23}$ Samsul Nizar, Filsafat Pendidikan Islam Pendekatan Historis, Teoritis, dan Praktis, (Jakarta: Ciputat Press, 2002), hlm. 26.

${ }^{24}$ Moh. Rofiq, Ilmu Pendidikan Islam Pengembangan Pendidikan Integratif di Sekolah, Keluarga, dan Masyarakat, (Yogyakarta: LKiS, 2009), hlm. 14. 
untuk memahami alam yang telah dididik oleh Allah sekaligus mampu mendekatkan diri kepada Allah Sang Pendidik Sejati. Sebagai makhluk Tuhan, manusia idealnya melakukan internalisasi secara kontinu (istiqamah) terhadap nilai-nilai ilabiyah agar mencapai derajat insan kamil sesuai dengan kehendak Allah swt ${ }^{25}$.

Nilai konsep tentang pendidikan Islam itu sendiri teramat luas jangkauannya karena menyangkut berbagai bidang yang berkaitan dengannya, mulai dari pengertian, dasar, tujuan, pendidik, subyek didik, alat-alat, kurikukum, pendekatan dan metode, lingkungan sampai pada lembaga pendidikan. Oleh karena itu, dalam buku ini penulis hanya akan membahasnya secara singkat dengan lebih memberikan titik tekan pada fungsi edukasi masjid sebagai pusat pendidikan dan pemberdayaan ${ }^{26}$. Penggunaan term al-tarbiyah untuk menunjuk makna pendidikan Islam dapat dipahami dengan merujuk firman Allah, yaitu : "Dan rendabkanlah dirimu terhadap mereka berdua dengan penuh kesayangan dan ucapkanlah: "Wabai Tubanku, kasibilah mereka keduanya, sebagaimana mereka berdua telah mendidik aku waktu kecil" Q.S. alIsra' [17]: 24 Uraian di atas, secara filosofis mengisyaratkan bahwa proses pendidikan Islam adalah bersumber pada pendidikan yang diberikan Allah sebagai "pendidik" seluruh ciptaanNya, termasuk manusia. Dalam konteks yang luas, pengertian pendidikan Islam yang dikandung dalam term al-tarbiyah terdiri atas empat unsur pendekatan, yaitu: (a) memelihara dan menjaga fitrah anak didik menjelang dewasa (baligh). (b) mengembangkan seluruh potensi menuju kesempurnaan. (c) mengarahkan seluruh fitrah menuju kesempurnaan. (d) melaksanakan pendidikan secara bertahap.Kedua, istilah al-ta'lim telah digunakan sejak periode awal pelaksanaan pendidikan Islam. Menurut para ahli, kata ini lebih bersifat universal dibanding dengan al-tarbiyah maupun alta'dib. Rasyid Ridha, misalnya mengartikan al-ta'lim sebagai proses transmisi berbagai ilmu pengetahuan pada jiwa individu tanpa adanya batasan dan ketentuan tertentu. Sebagaimana firman Allah Swt: "Sebagaimana (Kami telah menyempurnakan ni'mat Kami kepadamu)

\footnotetext{
${ }^{25}$ Ibid., hlm. 14.

${ }^{26}$ Ibid., hlm. 4.
} 
Kami telah mengutus kepadamu Rasul diantara kamu yang membacakan ayat-ayatKami kepada kamu dan mensucikan kamumengajarkan kepadamu Al Kitab dan Al-Hikmah (As Sunnab), serta mengajarkan kepada kamu apa yang belum kamu ketabui." Q.S. al-Baqarah [2]: 151. Kalimat wa yu'allimu hum al-kitab wa al-hikmah dalam Q.S. al-Baqarah [2]: 151 tersebut menjelaskan tentang aktivitas Rasulullah mengajarkan tilawat al-Qur'an kepada kaum muslimin. Menurut Abdul Fattah Jalal, apa yang dilakukan Rasul bukan hanya sekedar membuat umat Islam bisa membaca, melainkan membawa kaum muslimin kepada nilai pendidikan tazkiyah an-nafs (pensucian diri) dari segala kotoran, sehingga memungkinkannya menerima al-hikmah serta mempelajari segala yang bermanfaat untuk diketahui. Oleh karena itu, makna al-ta'lim tidak hanya terbatas pada pengetahuan yang lahiriyah, akan tetapi mencakup pengetahuan teoritis, mengulang secara lisan, pengetahuan dan keterampilan yang dibutuhkan dalam kehidupan, perintah untuk melaksanakan pengetahuan dan pedoman untuk berprilaku ${ }^{27}$.

Belajar atau sekolah sama-sama bermakna mencari ilmu yang merupakan bagian penting dari proses pendidikan yang pada intinya adalah transfer ilmu dan nilai moral. Ilmu berasal dari bahasa Arab 'a-l-m ("alima). Kata ilmu ini biasanya digabung dengan kata pengetahuan sehingga menjadi ilmu pengetahuan. Ilmu menurut terminologi diartikan sebagai suatu keyakinan yang mantap dan sesuai dengan fakta empirisnya, atau hasil gambaran berdasarkan rasio ${ }^{28}$.

Ketiga, pendidikan Islam disebut at-ta'dib. Menurut al-Attas, istilah yang paling tepat untuk menunjukkan pendidikan Islam adalah al-ta'dib. Konsep ini didasarkan pada hadits Nabi: "Tuban telah mendidikku, maka Ia sempurnakan pendidikanku”.(HR. Al-Askary dari 'Ali r.a.).

Kata addaba dalam hadits di atas dimaknai al-Attas sebagai "mendidik". Selanjutnya ia mengemukakan, bahwa hadits tersebut

\footnotetext{
${ }^{27}$ Samsul Nizar, Filsafat Pendidikan Islam Pendekatan Historis, Teoritis, dan Praktis,
} hlm. 28.

${ }^{28}$ Rofiq, Ilmu Pendidikan Islam Pengembangan Pendidikan Integratif di Sekolah, Keluarga, dan Masyarakat, hlm. 13. 
bisa dimaknai kepada "Tuhanku telah membuatku mengenali dan mengakui dengan adab yang dilakukan secara berangsurangsur ditanamkan-Nya kedalam diriku, tempat-tempat yang tepat bagi segala sesuatu didalam penciptaan, sehingga hal itu membimbingku kearah pengenalan dan pengakuan tempat-Nya yang tepat didalam tatanan wujud dan kepribadian, serta sebagai akibatnya Ia telah membuat pendidikanku yang paling baik.

Berdasarkan batasan tersebut, maka al-ta'dib berarti pengenalan dan pengakuan yang secara berangsur-angsur ditanamkan kedalam diri manusia (peserta didik) tentang tempat-tempat yang tepat dari segala sesuatu didalam tatanan penciptaan. Dengan pendekatan ini, pendidikan akan berfungsi sebagai pembimbing kearah pengenalan dan pengakuan tempat Tuhan yang tepat dalam tatanan wujud dan kepribadiannya ${ }^{29}$.

Terlepas dari perdebatan makna dari ketiga term diatas, secara terminologi, para ahli pendidikan Islam telah mencoba memformulasi pengertian pendidikan Islam. Diantara batasan yang sangat variatif tersebut adalah ${ }^{30}$.

a. al-Syaibaniy; mengemukakan bahwa pendidikan Islam adalah proses mengubah tingkah laku individu peserta didik pada kehidupan pribadi, masyarakat, dan alam sekitarnya. Proses tersebut dilakukan dengan cara pendidikan dan pengajaran sebagai suatu aktivitas asasi dan profesi diantara sekian banyak profesi asasi dalam masyarakat.

b. Muhmmad Fadhil al-Jamaly; mendefinisikan pendidikan Islam sebagai upaya mengembangkan, mendorong serta mengajak peserta didik hidup lebih dinamis dengan berdasarkan nilai-nilai yang tinggi dan kehidupan yang mulia. Dengan proses tersebut, diharapkan akan terbentuk pribadipeserta didik yang lebih sempurna, baik yang berkaitan dengan potensi akal, perasaan, maupun perbuatannya.

c. Ahmad D. Marimba; mengemukakan bahwa pendidikan hal. 30 .

${ }^{29}$ Nizar, Filsafat Pendidikan Islam Pendekatan Historis, Teoritis, dan Praktis, ${ }^{30}$ Ibid., hlm. 32. 
Islam adalah bimbingan atau pimpinan secara sadar oleh pendidik terhadap perkembangan jasmani dan rohani peserta didik menuju terbentuknya kepribadiannya yang utama (insan kamil).

d. Ahmad Tafsir; mendefinisikan pendidikan Islam sebagai bimbingan yang diberikan oleh seseorang agar ia berkembang secara maksimal sesuai dengan ajaran Islam.

\section{Simpulan}

Kebijakan perencanaan kurikulum pada program studi pendidikan agama Islam Sekolah Tinggi Agama Islam Negeri Kudus dilakukan dengan penyusunan secara periodik mulai kurikulum 1997, kurikulum 2003, dan kurikulum 2008. Kurikulum dari tiga periode itu dilakukan evaluasi dan penyusunan kembali hingga melibatkan para dosen dan ahli, baik dari dalam lembaga maupun ahli dari luar. Kurikulum disusun dengan mengacu pada Pedoman Penyusunan Kurikulum Pendidikan Tinggi dan Penilaian Hasil Belajar Mahasiswa. Jadi, kurikulum itu disebut kurikulum dengan pendekatan dengan pola corelated curriculum, yaitu pendekatan dengan pola pengelompokan beberapa mata kuliah yang serumpun. Artinya, kurikulum 2008 ini tidak kurikulum yang berpendekatan dengan polasubject matter curriculum, atau pendekatan yang menekankan pada mata kuliah secara terpisahpisah. Mata kuliah klasifikasikan menjadi 5 kelompok, yaitu mata kuliah pengembangan kepribadian (MPK), mata kuliah keilmuan dan keterampilan (MKK), mata kuliah keahlian berkarya (MKB), mata kuliah perilaku berkarya (MPB), mata kuliah berkehidupan bermasyarakat (MBB). Kurikulum STAIN Kudus Tahun 2008 sudah selangkah lebih maju. Namun, tantangan ke depan, para perencana kurikulum sebaiknya mempertimbangkan suatu pendekatan dengan polaintegrated curriculum, yaitu pendekatan dengan penyatuan keseluruhan mata kuliah sebagai bahan ajar yang sistematik-integralistik, khususnya untuk kepentingan pengarusutamaan pendekatan anti-radikalisme dalam kurikulum dan pembelajaran. 
Kisbiyanto

Isi kurikulum yang bermuatan materi anti-radikalisme dituangkan sebagai pokok bahasan atau sub pokok bahasan sebagai berikut.

\begin{tabular}{|c|c|c|}
\hline No & Mata Kuliah & Keterangan \\
\hline \multicolumn{3}{|c|}{ Semester I } \\
\hline 1 & $\begin{array}{l}\text { Pendidikan } \\
\text { Kewarganegaraan }\end{array}$ & $\begin{array}{l}\text { Nasionalisme dan kewarganegaraan } \\
\text { Indonesia yang berdasarkan } \\
\text { Pancasila, yang cinta damai }\end{array}$ \\
\hline 2 & Bahasa Indonesia & $\begin{array}{l}\text { Kecintaan berbahasa Indonesia } \\
\text { sebagai bahasa pergaulan, bahasa } \\
\text { pendidikan, dan bahasa dakwah } \\
\text { yang menyatukan semua komponen } \\
\text { bangsa }\end{array}$ \\
\hline 3 & Bahasa Arab I & $\begin{array}{l}\text { Kecintaan berbahasa Arab untuk } \\
\text { bahasa pendidikan dan bahasa } \\
\text { dakwah dengan mendalami ilmu-ilmu } \\
\text { agama Islam yang moderat dan cintai } \\
\text { damai }\end{array}$ \\
\hline 4 & Bahasa Arab II & $\begin{array}{l}\text { Kecintaan berbahasa Arab untuk } \\
\text { bahasa pendidikan dan bahasa } \\
\text { dakwah dengan mendalami ilmu-ilmu } \\
\text { agama Islam yang moderat dan cintai } \\
\text { damai }\end{array}$ \\
\hline 5 & Praktikum: Bahasa Arab & $\begin{array}{l}\text { Kecintaan berbahasa Arab untuk } \\
\text { bahasa pendidikan dan bahasa } \\
\text { dakwah dengan mendalami ilmu-ilmu } \\
\text { agama Islam yang moderat dan cintai } \\
\text { damai }\end{array}$ \\
\hline 6 & IAD, ISD, IBD & $\begin{array}{l}\text { Pemahaman bahwa semua ilmu } \\
\text { adalah bersifat interkonektif, } \\
\text { termasuk dengan disiplin ilmu alam, } \\
\text { ilmu sosial, ilmu humaniora, dan ilmu } \\
\text { keislaman }\end{array}$ \\
\hline 7 & Metodologi Studi Islam & $\begin{array}{l}\text { Metode berislam yang cerdas dan } \\
\text { moderat, dengan memahami Islam } \\
\text { sebagai dogma, sebagai ilmu, dan } \\
\text { sebagai way of life yang rahmat bagi } \\
\text { semua alam }\end{array}$ \\
\hline
\end{tabular}


Manajemen Kurikulum dalam Perspektif Anti-Radikalisme

\section{Semester II}

Penggunaan bahasa Inggris sebagai

1 Bahasa Inggris I bahasa keilmuan dan komunikasi internasional, bukan sebagai bahasa orang kafir

Penggunaan bahasa Inggris sebagai

2 Bahasa Inggris II bahasa keilmuan dan komunikasi internasional, bukan sebagai bahasa orang kafir

Penggunaan bahasa Inggris sebagai

3 Praktikum : Bahasa Inggris bahasa keilmuan dan komunikasi internasional, bukan sebagai bahasa orang kafir

Memahami kedalaman ilmu tentang

4 Ulumul Qur`an al-Qur'an sebagai metode berpikir dan bersikap ilmiah dan persatuan Islam

\begin{tabular}{|c|c|c|}
\hline 5 & Ulumul Hadis & $\begin{array}{l}\text { Memahami kedalaman ilmu tentang } \\
\text { hadis sebagai metode berpikir dan } \\
\text { bersikap ilmiah dan persatuan Islam }\end{array}$ \\
\hline 6 & Psikologi & $\begin{array}{l}\text { Memahami dasar-dasar psikologi } \\
\text { untuk kesadaran kemanusiaan }\end{array}$ \\
\hline 7 & Filsafat & $\begin{array}{l}\text { Memahami dasar-dasar filsafat untuk } \\
\text { berpikir rasional, tidak emosional }\end{array}$ \\
\hline \multicolumn{3}{|c|}{ Semester III } \\
\hline 1 & Praktikum : Ibadah & $\begin{array}{l}\text { Pelatihan praktik tentang model } \\
\text { beribadah yang kontekstual dengan } \\
\text { Islam di Indonesia yang toleran dan } \\
\text { menerima perbedaan madzhab }\end{array}$ \\
\hline 2 & Ushul Fiqih I & $\begin{array}{l}\text { Memahami metodologi penentuan } \\
\text { hukum Islam berdasarkan kaidah } \\
\text { logis dan benar, sehingga tidak } \\
\text { berpikir radikal }\end{array}$ \\
\hline 3 & Fiqih I (Ibadah) & $\begin{array}{l}\text { Pemahaman detail tentang } \\
\text { peribadatan berbagai madzhab } \\
\text { sehingga ada toleransi dan } \\
\text { menghargai perbedaan }\end{array}$ \\
\hline 4 & Statistik Deskriptif & $\begin{array}{l}\text { Pemahaman tentang penggunaan } \\
\text { data matematika untuk evaluasi dan } \\
\text { penelitian }\end{array}$ \\
\hline
\end{tabular}




\begin{tabular}{|c|c|c|}
\hline 5 & Sejarah Peradaban Islam & $\begin{array}{l}\text { Pemahaman yang mendalam tentang } \\
\text { sejarah peradaban Islam untuk tidak } \\
\text { radikal secara pemikiran karena } \\
\text { mengenal dengan baik sejarah masa } \\
\text { lalu }\end{array}$ \\
\hline 6 & Ilmu Pendidikan & $\begin{array}{l}\text { Pemahaman mendalam dasar- } \\
\text { dasar pendidikan dari sosiokultural } \\
\text { masyarakat agar berkepribadian dan } \\
\text { berbudaya }\end{array}$ \\
\hline 7 & $\begin{array}{l}\text { Pengembangan Kurikulum } \\
\text { PAI }\end{array}$ & $\begin{array}{l}\text { Pemahaman tentang kurikulum } \\
\text { dan pengembangannya, bidang } \\
\text { keagamaan Islam yang sesuai dengan } \\
\text { masyarakat Indonesia }\end{array}$ \\
\hline 8 & Ilmu Tauhid & $\begin{array}{l}\text { Pemahaman mendalam tentang } \\
\text { tauhid, aqidah, dan spiritual } \\
\text { keagamaan yang humanis }\end{array}$ \\
\hline \multicolumn{3}{|c|}{ Semester IV } \\
\hline 1 & $\begin{array}{l}\text { Praktikum : Teknologi } \\
\text { Informasi Pendidikan }\end{array}$ & $\begin{array}{l}\text { Penguasaan teknik penggunaan } \\
\text { dan pemanfaatan teknologi untuk } \\
\text { keperluan pengajaran }\end{array}$ \\
\hline 2 & Strategi Pembelajaran PAI & $\begin{array}{l}\text { Pemahaman tentang pembelajaran } \\
\text { dan pengembangannya, bidang } \\
\text { keagamaan Islam yang sesuai dengan } \\
\text { masyarakat Indonesia }\end{array}$ \\
\hline 3 & $\begin{array}{l}\text { Metodologi Penelitian } \\
\text { Kualitatif }\end{array}$ & $\begin{array}{l}\text { Pemahaman mendalam tentang } \\
\text { melaksanakan penelitian ilmiah } \\
\text { sebagai prosedur ilmiah dan rasional }\end{array}$ \\
\hline 4 & Statistik Inferensial & $\begin{array}{l}\text { Pemahaman tentang penggunaan } \\
\text { data matematika untuk evaluasi dan } \\
\text { penelitian }\end{array}$ \\
\hline 5 & Filsafat Pendidikan Islam & $\begin{array}{l}\text { Pemahaman mendalam berbagai } \\
\text { pemikiran dalam pendidikan Islam } \\
\text { yang berbasis kemanusiaan dan } \\
\text { keagamaan }\end{array}$ \\
\hline 6 & Ushul Fiqih II & $\begin{array}{l}\text { Memahami metodologi penentuan } \\
\text { hukum Islam berdasarkan kaidah logis } \\
\text { dan benar, sehingga tidak berpikir } \\
\text { radikal }\end{array}$ \\
\hline 7 & Ilmu Pendidikan Islam & $\begin{array}{l}\text { Pemahaman mendalam dasar-dasar } \\
\text { pendidikan dari al-Qur'an, hadis dan } \\
\text { sosiokulural masyarakat msulim agar } \\
\text { berkepribadian dan taat beragama }\end{array}$ \\
\hline
\end{tabular}


Manajemen Kurikulum dalam Perspektif Anti-Radikalisme

\begin{tabular}{|c|c|c|}
\hline 8 & Tafsir I (Tarbawi) & $\begin{array}{l}\text { Pemahaman yang komprehensif } \\
\text { tentang dasar teori-teori pendidikan } \\
\text { yang terdapat dalam al-Qur'an }\end{array}$ \\
\hline \multicolumn{3}{|r|}{ Semester V } \\
\hline 1 & $\begin{array}{l}\text { Praktikum : Penelitian } \\
\text { Pendidikan Islam }\end{array}$ & $\begin{array}{l}\text { Pelatihan dan praktik penelitian } \\
\text { sebagai pengasahan kemampuan } \\
\text { mahasiswa dalam mengejawantahkan } \\
\text { teori-teori penelitian dalam praktik } \\
\text { penelitian di wilayah pendidikan } \\
\text { Islam }\end{array}$ \\
\hline 2 & Perencanaan Sistem PAI & $\begin{array}{l}\text { Pemahaman tentang ancangan } \\
\text { pembelajaran bidang keagamaan } \\
\text { Islam yang sesuai dengan masyarakat } \\
\text { Indonesia }\end{array}$ \\
\hline 3 & $\begin{array}{l}\text { Metodologi Penelitian } \\
\text { Kuantitatif }\end{array}$ & $\begin{array}{l}\text { Pemahaman mendalam tentang } \\
\text { melaksanakan penelitian ilmiah } \\
\text { sebagai prosedur ilmiah dan rasional }\end{array}$ \\
\hline 4 & $\begin{array}{l}\text { Pengembangan Sistem } \\
\text { Evaluasi PAI }\end{array}$ & $\begin{array}{l}\text { Pemahaman tentang penilaian } \\
\text { dan evaluasi pembelajaran bidang } \\
\text { keagamaan Islam yang sesuai dengan } \\
\text { masyarakat Indonesia }\end{array}$ \\
\hline 5 & $\begin{array}{l}\text { Materi \& Pembelajaran } \\
\text { Qur'an Hadits MTs \& MA }\end{array}$ & $\begin{array}{l}\text { Pemahaman pelajaran dan pengajaran } \\
\text { al-Qur'an dan hadis yang sesuai } \\
\text { dengan masyarakat Indonesia }\end{array}$ \\
\hline 6 & $\begin{array}{l}\text { Materi \& Pembelajaran Fiqih } \\
\text { MTs \& MA }\end{array}$ & $\begin{array}{l}\text { Pemahaman pelajaran dan pengajaran } \\
\text { fiqih yang sesuai dengan masyarakat } \\
\text { Indonesia }\end{array}$ \\
\hline 7 & Fiqih II (Mu'amalah) & $\begin{array}{l}\text { Pemahaman detail tentang muamalah } \\
\text { berbagai madzhab sehingga ada } \\
\text { toleransi dan menghargai perbedaan }\end{array}$ \\
\hline 8 & Teknologi Pembelajaran PAI & $\begin{array}{l}\text { Pengetahuan tentang penggunaan } \\
\text { dan pemanfaatan teknologi untuk } \\
\text { pengajaran }\end{array}$ \\
\hline \multicolumn{3}{|c|}{ Semester VI } \\
\hline 1 & Praktikum : Micro Teaching & $\begin{array}{l}\text { Pelatihan dan praktik mengajar di } \\
\text { kampus }\end{array}$ \\
\hline 2 & $\begin{array}{l}\text { Materi \& Pembelajaran } \\
\text { Akidah Akhlak MTs \& MA }\end{array}$ & $\begin{array}{l}\text { Pemahaman pelajaran dan pengajaran } \\
\text { akidah dan akhlak yang sesuai dengan } \\
\text { masyarakat Indonesia }\end{array}$ \\
\hline
\end{tabular}




\begin{tabular}{|c|c|c|}
\hline & $\begin{array}{l}\text { Materi \& Pembelajaran SKI } \\
\text { MTs \& MA }\end{array}$ & $\begin{array}{l}\text { Pemahaman pelajaran dan pengajaran } \\
\text { SKI yang sesuai dengan masyarakat } \\
\text { Indonesia }\end{array}$ \\
\hline 4 & Filsafat Ilmu & $\begin{array}{l}\text { Pengetahuan tentang berpikir logis } \\
\text { dan tata cara keilmuan }\end{array}$ \\
\hline 5 & Psikologi Pendidikan & $\begin{array}{l}\text { Pemahaman tentang perilaku yang } \\
\text { baik dalam mendidik }\end{array}$ \\
\hline & Manajemen Pendidikan & $\begin{array}{l}\text { Pemahaman sistematis untuk } \\
\text { pengelolaan pendidikan secara efisien } \\
\text { dan efektif }\end{array}$ \\
\hline 7 & Hadis I (Tarbawi) & $\begin{array}{l}\text { Pemahaman tentang hadis secara } \\
\text { tekstual dan kontekstual }\end{array}$ \\
\hline 8 & Perencanaan Pendidikan & $\begin{array}{l}\text { Pemahaman tentang merencanakan } \\
\text { pengembangan lembaga pendidikan } \\
\text { yang baik }\end{array}$ \\
\hline & Sem & ster VII \\
\hline & $\begin{array}{l}\text { Praktik Profesi Lapangan } \\
\text { (PPL) }\end{array}$ & $\begin{array}{l}\text { Praktik mengajar dan berkolaborasi } \\
\text { dengan masyarakat pendidikan dai } \\
\text { sekolah/madrasah }\end{array}$ \\
\hline & Supervisi Pendidikan & $\begin{array}{l}\text { Pemahaman sistematis untuk } \\
\text { pengawasan pendidikan secara efisien } \\
\text { dan efektif }\end{array}$ \\
\hline & $\begin{array}{l}\text { Isu Kontemporer } \\
\text { Pendidikan Islam }\end{array}$ & $\begin{array}{l}\text { Pemahaman kritis tentang } \\
\text { perkembangan pendidikan Islam yang } \\
\text { transformatif dan berkeindonesiaan }\end{array}$ \\
\hline 4 & Bimbingan Dan Konseling & $\begin{array}{l}\text { Pemahaman tentang bimbangan dan } \\
\text { konseling dengan pendekatan Islam } \\
\text { tranformatif }\end{array}$ \\
\hline 5 & Tafsir II (Ahkami) & $\begin{array}{l}\text { Pemahaman tentang isi al-Qur'an } \\
\text { secara tekstual dan kontekstual }\end{array}$ \\
\hline 6 & Filsafat Islam & $\begin{array}{l}\text { Pengetahuan tentang berpikir logis } \\
\text { dan tata cara keislaman }\end{array}$ \\
\hline 7 & Hadis II (Ahkami) & $\begin{array}{l}\text { Pemahaman tentang hadis secara } \\
\text { tekstual dan kontekstual }\end{array}$ \\
\hline 8 & Bahtsul Kutub & $\begin{array}{l}\text { Pemahaman tentang sumber-sumber } \\
\text { kitab berbahasa Arab secara tekstual } \\
\text { dan kontekstual }\end{array}$ \\
\hline \multicolumn{3}{|r|}{ Semester VIII } \\
\hline & Psikologi Islam & $\begin{array}{l}\text { Pemahaman tentang perilaku yang } \\
\text { baik dalam beragama Islam }\end{array}$ \\
\hline
\end{tabular}


Manajemen Kurikulum dalam Perspektif Anti-Radikalisme

\begin{tabular}{cll}
\hline 2 & Psikologi Perkembangan & $\begin{array}{l}\text { Pemahaman tentang perilaku yang } \\
\text { baik dalam mendidik sesuai usia dan } \\
\text { perkembangan }\end{array}$ \\
\hline 3 & Ilmu Tasawuf & $\begin{array}{l}\text { Pemahaman perilaku dan akhlak yang } \\
\text { baik dalam agama Islam }\end{array}$ \\
\hline 4 & Profesi Keguruan & $\begin{array}{l}\text { Pemahaman etika dan kinerja } \\
\text { keguruan sesuai dengan latar } \\
\text { keagamaan Islam }\end{array}$ \\
\hline 5 & Sosiologi Pendidikan & $\begin{array}{l}\text { Pemahaman berinteraksi dengan } \\
\text { berbagai pihak masyarakat untuk } \\
\text { pengembangan pendidikan Islam }\end{array}$ \\
\hline 6 & Masail Fiqhiyah & $\begin{array}{l}\text { Pemahaman dan sikap yang } \\
\text { menghargai perbedaan dalam } \\
\text { masalah keagamaan Islam }\end{array}$ \\
\hline 7 & Perbandingan Agama & $\begin{array}{l}\text { Pemahaman dan sikap tentang } \\
\text { kerukunan beragama }\end{array}$ \\
\hline 9 & Kuliah Kerja Nyata (KKN) & $\begin{array}{l}\text { Praktik dan bersosialisasi dalam } \\
\text { masyarakat untuk dakwah dan } \\
\text { berkehidupan sosial }\end{array}$ \\
\hline
\end{tabular}


Kisbiyanto

\section{DAFTAR PUSTAKA}

Baharuddin, Prospektus Menuju World Class University dalam Reorientasi Tradisi Perguruan Tinggi Islam Menuju World Class University, Malang: UIN Maliki Press, 2014.

Bungin, Burhan, Analisis Data Penelitian Kualitatif - Pemahaman Filososfis dan Metodologis ke Arah Penguasaan Model Aplikasi, Jakarta: PT. RajaGrafindo Persada, 2003.

Chotimah, Chusnul dan Muhammad Fathurrohman, Komplemen Manajemen Pendidikan Islam - Konsep Integratif Pelengkap Manajemen Pendidikan Islam, Yogyakarta: Teras , 2014.

Hubeis, Musa dan Mukhamad Najib, Manajemen Strategik dalam Pengembangan Daya Saing Organisasi, Jakarta: Elex Media Komputindo, t.t.

Majid, Abdul, Strategi Pembelajaran, Bandung: Remaja Rosdakarya, 2013.

Masykur Musa, Ali, Nasionalisme di Persimpangan - Pergumulan NU dan Paham Kebangsaan Indonesia, Jakarta: Penerbit Erlangga, 2011.

McMillan, James H and Sally Schumacher, Research In Education A Conceptual Introduction, San Francisco: Longman, 2001.

Milal Bizawie, Zainul, Laskar Ulama-Santri \& Resolusi Jihad Garda Depan Menegakean Indonesia 1945-1949, Ciputat Tangerang: Penerbit Compass, 2014.

Miles B Matthew dan Huberman, Analisis Data Kualitatif (terj. Tjetjep Rohendi), Jakarta: UI, t.t.

Moleong, Lexy J, Metodologi Penelitian Kualitatif, Jakarta: Rake Sarasin, 2000.

Nizar, Samsul, Filsafat Pendidikan Islam Pendekatan Historis, Teoritis, dan Praktis, Jakarta: Ciputat Press,, 2002.

Norman K Denzim and Yvonna S Lincold, Handbook of Qualitative Research (Second Edition), California: Sage Publication, Inc., 2000.

Rofiq, Moh, Ilmu Pendidikan Islam Pengembangan Pendidikan Integratif di Sekolah, Keluarga, dan Masyarakat, Yogyakarta: 
LKiS, 2009.

S. Nasution, Metode Penelitian Naturalistik Kualitatif, Jakarta: Tarsito, Bandung, 1996.

S. Nasution, Pengembangan dan Inovasi Kurikulum, PT. Citra Aditya Bakti, 1993.

Soetopo, Henyat dan Wasty Soemanto, 1986. Pembinaan dan Pengembangan Kurikulum, Jakarta: PT. Bima Aksara, 1986.

Sriningsih, Retno Satmoko Landasan Kependidikan : Pengantar ke Arah Ilmu Pendidikan Pancasila, Semarang: CV. IKIP Semarang Press, 1999.

St. Vembriarto, Pengantar Perencanaan Pendidikan, PT. Grasindo, Jakarta, 1993.

Subandijah, Pengembangan dan Inovasi Kurikulum, Jakarta: PT. Raja Grafindo Persada, 1996.

Sugiyono, Metode Penelitian Pendidikan Pendekatan Kuantitatif, Kualitatif dan R \& D, Bandung: Alfabeta, 2008.

Tilaar, HAR. 1999. Pendidikan, Kebudayaan dan Masyarakat Madani Indonesia. Bandung: PT. Remaja Rosda Karya, 1999.

Tjiptono, Fandy dan Anastasia Diana, TotalQuality Manaaagement, Yogyakarta: Penerbit Andi, 2000. 
Kisbiyanto

Halaman ini tidak sengaja untuk dikosongkan 